Julia Scheel • Ragna Hussong • Dieter Schrenk

Hans-Joachim Schmitz

\title{
Variability of the human aryl hydrocarbon receptor nuclear translocator (ARNT) gene
}

Received: December 20, 2001 / Accepted: February 7, 2002

\begin{abstract}
The aryl hydrocarbon receptor nuclear translocator (ARNT) plays an essential role in vertebrate transcriptional regulation as the common subunit of transcriptionally active complexes like the aryl hydrocarbon receptor (AHR)/ARNT heterodimer and hypoxiainducible factor 1 , mediating cellular responses to certain xenobiotics and to hypoxia, respectively. A cohort of healthy Caucasian volunteers was screened for genetic variations of $A R N T$. Six polymorphic sites could be identified, a variation in a G-stretch upstream of the ATG translation start site, a frequent silent mutation (G567C), two polymorphic sites in intron 9 , and two single nucleotide substitutions leading to amino acid exchanges, G1531A (D511N) and T1551G (D517E). The frequencies were 0.005 for the Asn-coding allele and for the Glu-coding allele, respectively, with no linkage between these two mutations. Although no significant correlation with activities of CYP1A2, which is under regulatory control of the AHR/ ARNT transcription complex, could be established, metabolic or pathological phenotypes may be associated with these variations.
\end{abstract}

Key words Human · ARNT · AHR · Aryl hydrocarbon receptor $\cdot$ Genetic polymorphism $\cdot$ Genetic variation

\section{Introduction}

The aryl hydrocarbon receptor nuclear translocator (ARNT) is a member of the basic helix-loop-helix/PERARNT-SIM (bHLH/PAS) family of proteins. ARNT is ubiquitously expressed in vertebrate tissues. Disruption

J. Scheel · R. Hussong · D. Schrenk · H.-J. Schmitz

Food Chemistry and Environmental Toxicology, University of Kaiserslautern, Kaiserslautern, Germany

J. Scheel $(\square)$

Axaron Bioscience AG, Im Neuenheimer Feld 515, D-69120

Heidelberg, Germany

Tel. +49-6221-454-804; Fax +49-6221-454-700

e-mail: scheel@axaron.com of ARNT by homologous recombination results in embryonic death of mice because of abortive angiogenesis and defective responses to glucose and oxygen deprivation. The $\mathrm{Arnt}^{-1-}$-mice are not viable past gestation day 10.5 (Maltepe et al. 1997; Kozak et al. 1997).

ARNT acts as a common structural subunit of homodimeric and heterodimeric transcriptionally active complexes and participates in many regulatory processes (Schmidt and Bradfield 1996; Rowlands and Gustafsson 1997; Wilson and Safe 1998). The most prominent example is the aryl hydrocarbon receptor (AHR)/ARNT-mediated response to certain xenobiotics, leading to induction of a number of phase I and II drug-metabolizing enzymes, encoded by the so-called $A H R$ gene battery. The environmental contaminant 2,3,7,8-tetrachlorodibenzo- $p$-dioxin ("dioxin") is the prototype ligand representing a broad group of halogenated aromatic hydrocarbons, including polychlorinated dibenzodioxins, dibenzofurans, and biphenyls (Schrenk 1998). On ligand binding, AHR undergoes a rapid transformation process whereby it releases heat shock protein 90 and hepatitis B virus X-associated protein 2, translocates to the nucleus, and dimerizes with ARNT (Okey et al. 1980; Reyes et al. 1992). The resulting heterodimeric transcription complex subsequently binds to enhancer elements, referred to as xenobiotic response elements, in the $5^{\prime}$-flanking region of AHR-dependent genes, leading to enhanced expression of the respective enzymes. Among these are the phase I enzymes CYP1A1 and CYP1A2, which are responsible for the activation of several procarcinogenic compounds to carcinogenic metabolites. Elevated levels of these enzymes, resulting either from a genetic polymorphism or from exposure to an inducer, i.e., an AHR ligand, might predispose individuals to cancer. Interindividual differences in CYP1A1 and CYP1A2 activity have been previously reported in several studies (Butler et al. 1992; Smart and Daly 2000; Schrenk et al. 1998).

Another signaling pathway that has attracted much interest in the last few years is the cellular response toward hypoxic conditions through hypoxia-inducible factor 1 (HIF-1), composed of HIF-1 $\alpha$ and ARNT (HIF-1 $\beta$ ), leading, for example, to upregulation of the erythropoietin 
(EPO) gene (Wenger and Gassmann 1997). ARNT can also form homodimers that potentially activate E-box controlled genes (Sogawa et al. 1995). ARNT has been mapped to a conserved linkage group located on human chromosome 1 on q21 (Johnson et al. 1993) and is within a region that has shown linkage to metabolic disorders, such as partial lipodystrophy and familial combined hyperlipidemia (Anderson et al. 1999; Pajukanta et al. 1998). There are lines of evidence that ARNT may be linked to regulatory processes involved in Down syndrome (Chen et al. 1995; Ema et al. 1996). Very recently, it has been shown that the $\mathrm{t}(1 ; 12)(\mathrm{q} 21 ; \mathrm{p} 13)$ translocation found in human acute myeloblastic leukemia results in a translocated E26 transformation-specific leukemia (TEL)-ARNT fusion (Salomon-Nguyen et al. 2000). Therefore, genetic variation in $A R N T$ is of fundamental scientific interest and may be of clinical relevance as well.

Few data exist about the genetic variability of $A R N T$. Recently, an $A R N T$ polymorphism in codon 511, G1531A, resulting in an D511N exchange in exon 16, has been identified in subjects with partial lipodystrophy (Cao and Hegele 2000). The frequency of the Asn-coding allele was shown to be 0.019 in Caucasians and 0.026 in Africans, and the frequency of the Asp-coding allele was 0.981 and 0.974, respectively. Mendelian inheritance was confirmed in two large families. This polymorphism could not be detected in a Japanese cohort, suggesting that this polymorphism is rare or even absent in the Japanese population (Watanabe et al. 2001). A silent single nucleotide mutation has been reported in codon 189 of $A R N T$ (Anttila et al. 2000). In addition, $A R N T$ shows a restriction fragment length polymorphism for MspI (Johnson et al. 1992). So far, none of these polymorphisms could be assigned to a functional alteration.

To screen for genetic variations, we investigated the entire coding region and about $1 \mathrm{~kb}$ of the $5^{\prime}$-flanking region of the human $A R N T$ gene by polymerase chain reaction (PCR)-SSCP (single-strand conformational polymorphism) analysis in a cohort of healthy Caucasian volunteers. In parallel, CYP1A2 activity was determined by analysis of urinary caffeine metabolites. Each genetic variation was compared with the urinary metabolic ratio of caffeine metabolites $\left(\mathrm{MR}_{\mathrm{C}}\right.$ values) by comparison of data and statistical correlation analysis, respectively.

\section{Subjects and methods}

\section{PCR-SSCP analysis}

Blood samples were collected from a cohort of unrelated healthy Caucasian volunteers, comprising 79 individuals (37 female nonsmokers, 42 male nonsmokers). Ethical approval was obtained from the local Ethical Committee and informed written consent was obtained from all subjects.

Isolation of mononuclear cells from peripheral blood was performed using the VACUTAINER CPT system (Becton Dickinson, Heidelberg, Germany). Genomic DNA for PCR was isolated with the QIAamp Blood Maxi Kit (Qiagen, Hilden, Germany) according to the instructions of the manufacturer. Based on the genomic sequence of ARNT (Scheel and Schrenk 2000), oligonucleotides were designed to cover the entire coding region and about $1 \mathrm{~kb}$ of the 5'-flanking region with PCR fragments of appropriate size for subsequent SSCP analysis (Fig. 1). To create PCR products comprising each exon, primers were directed to neighboring intronic sequences. For detailed sequence information on human $A R N T$, see GenBank accession numbers Y18859, AJ251863, AJ404851-4, and M69238. Oligonucleotide synthesis was performed by commercial
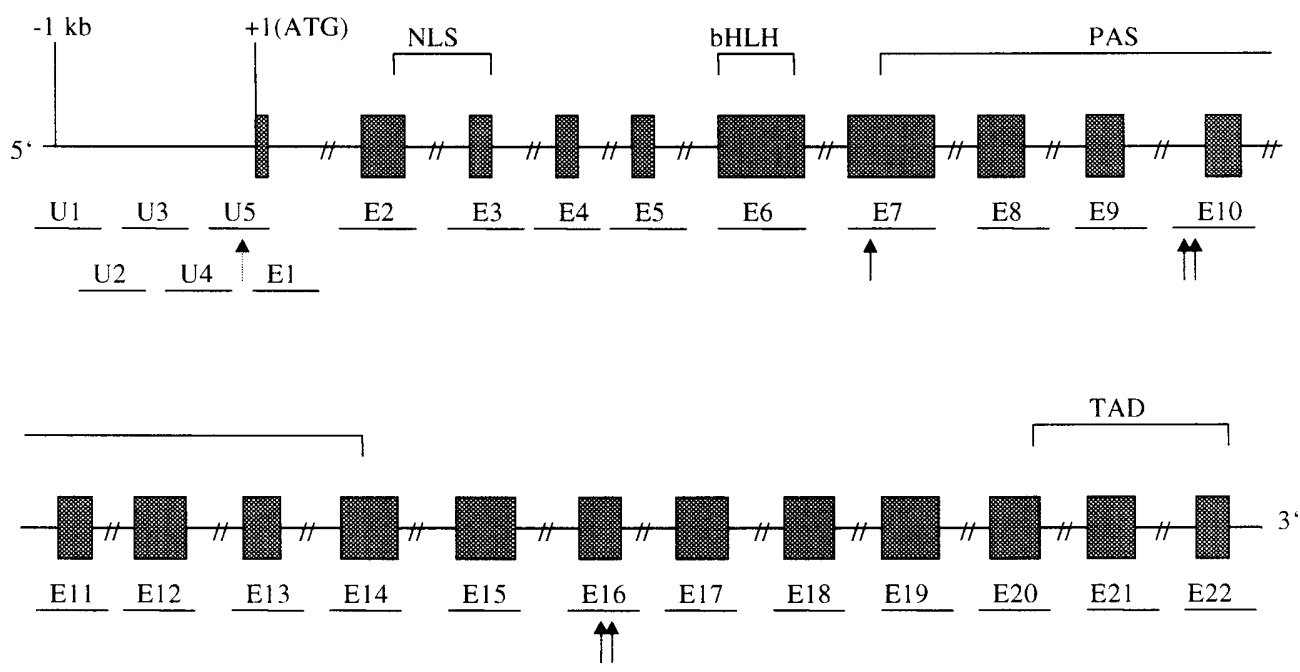

Fig. 1. Overview of the structure of the human $A R N T$ gene and the respective single-strand conformational polymorphism (SSCP) fragments generated for analysis of the genetic variability (not drawn to scale). About $1 \mathrm{~kb}$ of the $5^{\prime}$-flanking region was covered with five overlapping fragments. Each exon was analyzed by one fragment. Functional domains are given above the exons according to Wilson and
Safe (1998). Genetic variations are indicated by arrows. The broken arrow represents a genetic variation that could not be detected by SSCP. NLS, nuclear localization signal; $T A D$, transcriptional activation domain; bHLH, basic helix-loop-helix; PAS, PER-ARNT-SIM; $U 1-U 5$, polymerase chain reaction (PCR) fragments located in the 5 '-flanking region; E1-E22, PCR fragments covering exons 
Table 1. Primers and annealing temperatures used for PCR-SSCP analysis

\begin{tabular}{|c|c|c|c|}
\hline PCR fragment & Primer sequences & $\mathrm{T}_{\mathrm{a}}^{\mathrm{a}}$ & Product size (bp) \\
\hline \multirow{2}{*}{$\begin{array}{l}\mathrm{U} 1 \\
(-1013 \text { to }-742)\end{array}$} & 5'-TTTCTTCATCCATTGCCTCC-3' (U1for) & $60^{\circ} \mathrm{C}$ & 262 \\
\hline & 5'-TGGATTCGTCTAAGTGGTTGC-3' (U1rev) & & \\
\hline \multirow{2}{*}{$\begin{array}{l}\mathrm{U} 2 \\
(-882 \text { to }-572)\end{array}$} & 5'-TTCACCAGGGACAAAAGTCC-3' (U2for) & $68^{\circ} \mathrm{C}-61^{\circ} \mathrm{C}$ & 311 \\
\hline & 5'-TGTAATCCCAGCTTCTTGGG-3' (U2rev) & & \\
\hline \multirow{2}{*}{$\begin{array}{l}\text { U3 } \\
(-646 \text { to }-339)\end{array}$} & 5'-GGTATCTCGGCTCACTGCAA-3' (U3for) & $70^{\circ} \mathrm{C}-55^{\circ} \mathrm{C}$ & 308 \\
\hline & 5'-CCTAATCTCGCCCTCCTTGC-3' (Ü3rev) & & \\
\hline \multirow{2}{*}{$\begin{array}{l}\mathrm{U} 4 \\
(-378 \text { to }-83)\end{array}$} & 5'-CTCGGTCATTGACCTCTTAC-3' (U4for) & $60^{\circ} \mathrm{C}$ & 296 \\
\hline & 5'-AGAAAGGCCACTCCCCAGAA-3' (U4rev) & & \\
\hline \multirow{2}{*}{$\begin{array}{l}\text { U5 } \\
(-276 \text { to }+21)\end{array}$} & 5'-TGCCCTTGGACGATTTGG-3' (U5for) & $60^{\circ} \mathrm{C}$ & $293-297$ \\
\hline & 5'-GTTGGCAGTAGTCGCCGC-3' (U5rev) & & \\
\hline \multirow[t]{2}{*}{ Exon 1} & 5'-ATCTTGGATTCCGCGGTAGA-3' (E1for) & $71^{\circ} \mathrm{C}-66^{\circ} \mathrm{C}$ & 420 \\
\hline & 5'-CAACGGAGGACAGGACA-3' (E1rev) & & \\
\hline \multirow[t]{2}{*}{ Exon 2} & 5'-AATCTGGATATGAGCATTTGGG-3' (E2for) & $60^{\circ} \mathrm{C}$ & 363 \\
\hline & 5'-GTGAGATGGTCAGGAATAGCG-3' (E2rev) & & \\
\hline \multirow[t]{2}{*}{ Exon 3} & 5'-TGTTCCGGTAGCTTGTG-3' (E3for) & $65^{\circ} \mathrm{C}-58^{\circ} \mathrm{C}$ & 328 \\
\hline & 5'-CTCCTCACTGAGGTCCTT-3' (E3rev) & & \\
\hline \multirow[t]{2}{*}{ Exon 4} & 5'-CAAGTGTAATGCTTTGAAAC-3' (E4for) & $65^{\circ} \mathrm{C}-58^{\circ} \mathrm{C}$ & 191 \\
\hline & 5'-AATTCCGTCTCATCCAG-3' (E4rev) & & \\
\hline \multirow[t]{2}{*}{ Exon 5} & 5'-GCCTATAATTCCATTTCCCTCC-3' (E5for) & $60^{\circ} \mathrm{C}-55^{\circ} \mathrm{C}$ & 295 \\
\hline & 5'-TAGAAAAAGCAGCATCATCTGC-3' (E5rev) & & \\
\hline \multirow[t]{2}{*}{ Exon 6} & 5'-TGGGGCTTCTCTTTCTTTCC-3' (E6for) & $60^{\circ} \mathrm{C}$ & 292 \\
\hline & 5'-TCAAGAGATTCACCCAGATTCC-3' (E6rev) & & \\
\hline \multirow[t]{2}{*}{ Exon 7} & 5'-GTGTCTTACTTCTTCCTGTG-3' (E7for) & $60^{\circ} \mathrm{C}$ & 332 \\
\hline & 5'-AGGACTTCTCATTCATTTC-3' (E7rev) & & \\
\hline \multirow[t]{2}{*}{ Exon 8} & 5'-TTCATCTCCTGCTTGGTCAG-3' (E8for) & $60^{\circ} \mathrm{C}$ & 345 \\
\hline & 5'-TCCACTGGAGCTAATCCAAC-3' (E8rev) & & \\
\hline \multirow[t]{2}{*}{ Exon 9} & 5'-GTCTGGTTGTATCCAGAGCATG-3' (E9for) & $60^{\circ} \mathrm{C}$ & 273 \\
\hline & 5'-GATGCAAGTGAGAGCTGCTG-3' (E9rev) & & \\
\hline \multirow[t]{2}{*}{ Exon 10} & 5'-CCTCCTACTGCATACCTTTTGG-3' (E10for) & $57^{\circ} \mathrm{C}$ & 345 \\
\hline & 5'-TCATGGACTCTGTGAGGAACC-3' (E10rev) & & \\
\hline \multirow{2}{*}{ Exon 11} & 5'-CTTGGCTTCCCAAAGTGTTG-3' (E11for) & $65^{\circ} \mathrm{C}-58^{\circ} \mathrm{C}$ & 286 \\
\hline & 5'-GGAATGAGTCCTGAAGATCTGC-3' (E11rev) & & \\
\hline \multirow[t]{2}{*}{ Exon 12} & 5'-CAAAAGACCATGAGGAGATAGG-3' (E12for) & $60^{\circ} \mathrm{C}$ & 297 \\
\hline & 5'-TGGCTGTCTTAGGAACTACATG-3' (E12rev) & & \\
\hline \multirow[t]{2}{*}{ Exon 13} & 5'-AGTGCCTGCCACAGTGTTCA-3' (E13for) & $60^{\circ} \mathrm{C}$ & 266 \\
\hline & 5'-CAAGATCGCGCCATCGTA-3' (E13rev) & & \\
\hline \multirow[t]{2}{*}{ Exon 14} & 5'-GAAAAATATTGGTGCCTCAAGG-3' (E14for) & $60^{\circ} \mathrm{C}$ & 350 \\
\hline & 5'-GGGCATCAGAAGTGTTTTCTG-3' (E14rev) & & \\
\hline \multirow[t]{2}{*}{ Exon 15} & 5'-ССТСТССАСССССТСТTТАС-3' (E15for) & $60^{\circ} \mathrm{C}$ & 215 \\
\hline & 5'-TGGGATTGCAAATGACCAC-3' (E15rev) & & \\
\hline Exon 16 & 5'-AGTGTTGGGATTACAGGCATG-3' (E16for) & $71^{\circ} \mathrm{C}-60^{\circ} \mathrm{C}$ & 267 \\
\hline & 5'-GTACCGGAGAACACTTCCTAAG-3' (E16rev) & & \\
\hline Exon 17 & 5'-AGGGGTATTGAATTGTCATGTT-3' (E17) & $60^{\circ} \mathrm{C}$ & 266 \\
\hline & 5'-TGGAAGATTACTGACTGGGC-3' (E17) & & \\
\hline Exon 18 & 5'-CCCAGTCAGTAATCTTCCAGTG-3' (E18) & $60^{\circ} \mathrm{C}$ & 322 \\
\hline & 5'-AAGTAACCAGAGAAAGCAAGGG-3' (E18) & & \\
\hline Exon 19 & 5'-TGATTCCTAGCTTCTGTGATAAATC-3' (E19) & $60^{\circ} \mathrm{C}$ & 237 \\
\hline & 5'-GGGAACACACAGATGATAAGTTT-3' (E19) & & \\
\hline Exon 20 & 5'-GACTCTCATAGGCATGG-3' (E20for) & $60^{\circ} \mathrm{C}$ & 256 \\
\hline & 5'-CTTATGGTCTGGACTCAC-3' (E20rev) & & \\
\hline Exon 21 & 5'-GTGGCATTAGTACACAATGG-3' (E21for) & $62^{\circ} \mathrm{C}-61^{\circ} \mathrm{C}$ & 303 \\
\hline & 5'-CACTGTCTCTCCTCCTCCT-3' (E21rev) & & \\
\hline Exon 22 & 5'-GGAATGGTGGAGTAGAACTTGG-3' (E22for) & $60^{\circ} \mathrm{C}$ & 300 \\
\hline & 5'-AGGGAAAGGGGGTACATGTC-3' (E22rev) & & \\
\hline
\end{tabular}

PCR-SSCP, Polymerase chain reaction-single-strand conformational polymorphism; $\mathrm{T}_{\mathrm{a}}$, annealing temperature

${ }^{a}$ Where a range of annealing temperatures is given, a touchdown thermal profile was used

suppliers. The primers used are shown in Table 1. Genomic DNA samples $(100 \mathrm{ng})$ were used in 50- $\mu$ l PCR reactions containing $20 \mathrm{mM}$ Tris- $\mathrm{HCl}$ ( $\mathrm{pH} 8.4$ ), $50 \mathrm{mM} \mathrm{KCl}, 1.5 \mathrm{mM}$ $\mathrm{MgCl}_{2}, 200 \mu \mathrm{M}$ each of the deoxynucleotide triphosphates, $1 \mu \mathrm{M}$ each of the primers, and $25 \mathrm{mU} / \mu \mathrm{l}$ Taq polymerase. Thermal cycling was perfomed as follows: initial denaturation, $1 \mathrm{~min}$ at $95^{\circ} \mathrm{C} ; 30$ cycles of amplification with denaturation, $20 \mathrm{~s}$ at $95^{\circ} \mathrm{C}$; annealing, $2 \mathrm{~min}$ at annealing temperature (see Table 1); elongation, $1 \mathrm{~min}$ at $72^{\circ} \mathrm{C}$; and final extension, $10 \mathrm{~min}$ at $72^{\circ} \mathrm{C}$. PCR-amplified genomic fragments were heat denatured and separated via native PAGE (Jaeckel et al. 1998). Five microliters of PCR product was incubated with $7.5 \mu \mathrm{l}$ denaturing buffer $(92 \%$ formamide, $0.01 \%$ bromphenol blue, $0.01 \%$ xylene cyanol, $20 \mathrm{mM}$ ethylenediaminetetraacetate [EDTA], $20 \mathrm{mM}$ $\mathrm{NaOH}$ ) at $97^{\circ} \mathrm{C}$ for $10 \mathrm{~min}$. A double-strand control was 
included in each run (non-denaturing loading buffer contains $94 \%$ formamide, $0.01 \%$ bromophenol blue, $0.01 \%$ xylene cyanol, $20 \mathrm{mM}$ EDTA). The samples were immediately placed on ice for $5 \mathrm{~min}$. Ten microliters of the mixture was loaded onto a precooled $10 \%$ acrylamide gel and run with $30 \mathrm{~mA}$ at $4{ }^{\circ} \mathrm{C}$ for several hours.

\section{5'-RACE}

Determination of putative transcription start sites was performed as previously described (Scheel and Schrenk 2000). In brief, 5' cDNA ends were amplified according to the protocol of Life Technologies (Karlsruhe, Germany). Elongated bands were cloned and sequenced.

Sequence analysis of PCR products

PCR products were gel purified with the GENECLEAN Kit, cloned into the pCR II-TOPO vector (Invitrogen, Groningen, Netherlands), and sequenced with standard primers on an LI-COR 4000L sequencer (MWG-Biotech, Ebersberg, Germany), using the Thermo Sequenase fluorescence-labeled primer cycle sequencing kit (Amersham, Freiburg, Germany). In the case of an identified variant, six clones of the same genomic sample were sequenced to test for heterozygosity.

\section{Determination of CYP1A2 activity}

Urine was collected from all 79 individuals (42 males, 37 females) for $6 \mathrm{~h}$ after intake of caffeine. For CYP1A2 phenotyping, urine was analyzed for representative caffeine metabolites by high performance liquid chromatography (Beckman, Palo Alto, CA, USA) on an ODS RP column as described elsewhere (Schrenk et al. 1998). CYP1A2 activity was calculated as the CYP1A2-dependent metabolic ratio of caffeine $\left(\mathrm{MR}_{\mathrm{C}}\right)$, where $\mathrm{MR}_{\mathrm{C}}=[\mathrm{AFMU}+1 \mathrm{X}+1 \mathrm{U}] / 17 \mathrm{U}$ (AFMU, 5-acetylamino-6-formylamino-3-methyluracil; 1U, 1-methyluric acid; 1X, 1-methylxanthine; 17U, 17methyluric acid).

Genetic analysis

Analysis of linkage disequilibrium was carried out with genotypic data by use of the Software Arlequin 2.001 from the Genetics and Biometry Laboratory at the University of Geneva, Switzerland.

Statistical analysis

Statistical evaluation of genotypes and caffeine testing data was perfomed using the program InStat, version 3.0 for Windows (GraphPad, San Diego, CA, USA) and Origin, version 6 for Windows (Microcal, Northampton, MA, USA).

\section{Results}

PCR-SSCP analysis of the coding region of ARNT

Figure 1 gives an overview of the genomic structure of $A R N T$ and of the fragments amplified by PCR. In exon 7, three variant patterns could be detected by SSCP-polyacrylamide gel electrophoreses (PAGE) (see Fig. 2). Sequence
Fig. 2a-c. SSCP analysis of the human $A R N T$ gene. Representative SSCP patterns of genetic variants. a Exon 7, position 567. Lane 1, C/C genotype; lane 2, C/ $\mathrm{G}$ genotype; lane 3, G/G genotype. b Intron 9, positions 326 and 381 . Lanes 1 and $7,326(\mathrm{C} / \mathrm{C})$ / 381(T/T) genotype; lanes 2, 3, and $8,326(\mathrm{C} / \mathrm{C}) / 381(\mathrm{~T} / \mathrm{G})$ genotype; lane $4,326(\mathrm{C} / \mathrm{G}) / 381(\mathrm{~T} / \mathrm{T})$ genotype; lane $5,326(\mathrm{C} / \mathrm{C}) /$ $381(\mathrm{G} / \mathrm{G})$ genotype; lane 6, 326(G/G) / 381(T/T) genotype. c Exon 16, positions 1531 and 1551. Lane 1, 1531(G/A) / 1551(T/T) genotype; lanes 2, 3, and $4,1531(\mathrm{G} / \mathrm{G}) / 1551(\mathrm{~T} / \mathrm{T})$ genotype; lane 5, 1531(G/G) / $1551(\mathrm{~T} / \mathrm{G})$ genotype

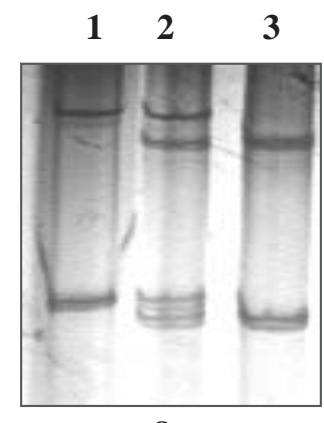

a

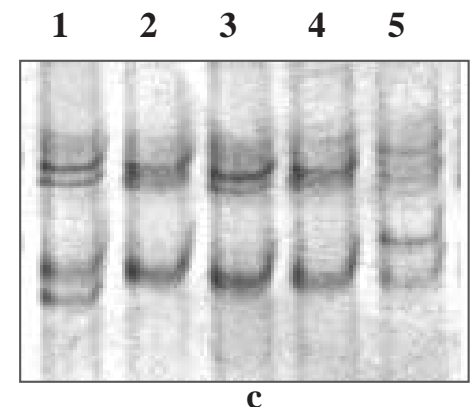

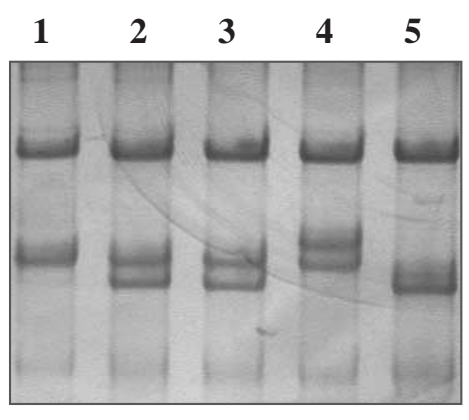

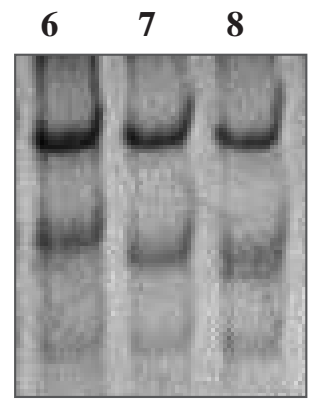

b 
Table 2. Allelic frequencies of genetic variations in human $A R N T$

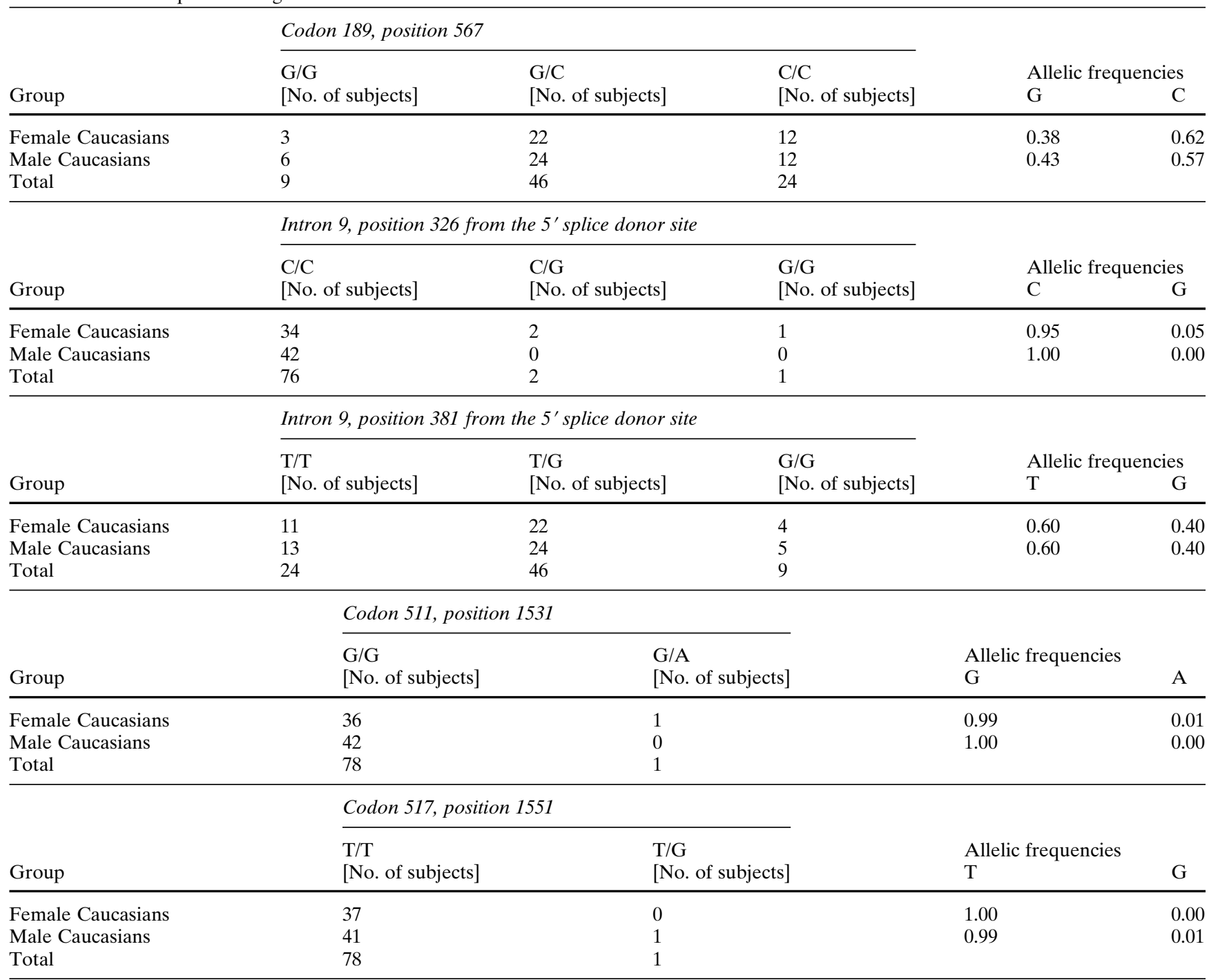

analysis revealed that they were due to a polymorphism located in the last base of codon 189, resulting in a silent mutation (G567C). The sample in lane 1 is homozygous for $\mathrm{C}$ (C/C genotype), lane 3 shows homozygosity for $\mathrm{G}(\mathrm{G} / \mathrm{G}$ genotype), and lane 2 shows fragments heterozygous for $\mathrm{G}$ and $\mathrm{C}(\mathrm{C} / \mathrm{G}$ genotype $)$. The distribution of the three forms in exon 7 of $A R N T$ fits quite well the Hardy-Weinberg expectations (compare Table 2). On the basis of the allele frequencies, 18 subjects per 100 are predicted for the $\mathrm{G} / \mathrm{G}$ genotype in position 567, whereas 9 were found among 79 . Likewise, for $\mathrm{G} / \mathrm{C}, 49$ are predicted per 100 , and 46 were found among 79; for $\mathrm{C} / \mathrm{C}, 34$ are predicted per 100 and 24 were detected among 79 .

The PCR-SSCP analysis aimed at exon 10 and surrounding intronic sequences revealed five variant forms (see Fig. 2). Sequence analysis of PCR clones related to each pattern indicated two polymorphic sites at positions 326 and 381 from the $5^{\prime}$ splice donor site of intron 9. The five patterns can be explained as follows: lanes 2, 3, and 8, C/C at 326, T/ $\mathrm{G}$ at 381; lanes 1 and 7, $\mathrm{C} / \mathrm{C}$ at $326, \mathrm{~T} / \mathrm{T}$ at 381 ; lane $5, \mathrm{C} / \mathrm{C}$ at $326, \mathrm{G} / \mathrm{G}$ at 381 ; lane $4, \mathrm{C} / \mathrm{G}$ at $326, \mathrm{~T} / \mathrm{T}$ at 381 ; lane $6, \mathrm{G} /$ $\mathrm{G}$ at 326, T/T at 381. Allelic frequencies are listed in Table 2. The intron 9, position 326 genotype distribution does not fit the Hardy-Weinberg law except for the homozygous genotype $\mathrm{C} / \mathrm{C}$. The intron 9 , position 381 genotype, however, shows a distribution similar to the exon 7 polymorphism. This observation was supported by detection of a significant linkage disequilibrium between these two loci $(P<0.05)$.

The exon 16-directed PCR-SSCP analysis resulted in three variant PAGE band patterns (Fig. 2), which originate from two variations leading to two amino acid exchanges (D511N and D517E). Samples in lanes 2-4 are homozygous for codon 511 (G/G genotype) and for codon 517 (T/T genotype); lane 5 displays homozygosity for codon 511 (G/ G genotype) and heterozygosity for codon 517 (T/G genotype); and lane 1 shows heterozygosity for codon 511 (G/A genotype) and homozygosity for codon 517 (T/T genotype). Allelic frequencies are listed in Table 2. One individual of the cohort shows the G1531A variation (D511N) and one 
Fig. 3. DNA sequence analysis of variant forms in a region harboring three putative transcription start sites. Transcription start sites are indicated in bold type. Numbering of the bases is performed by setting the first base of the ATG start codon as +1

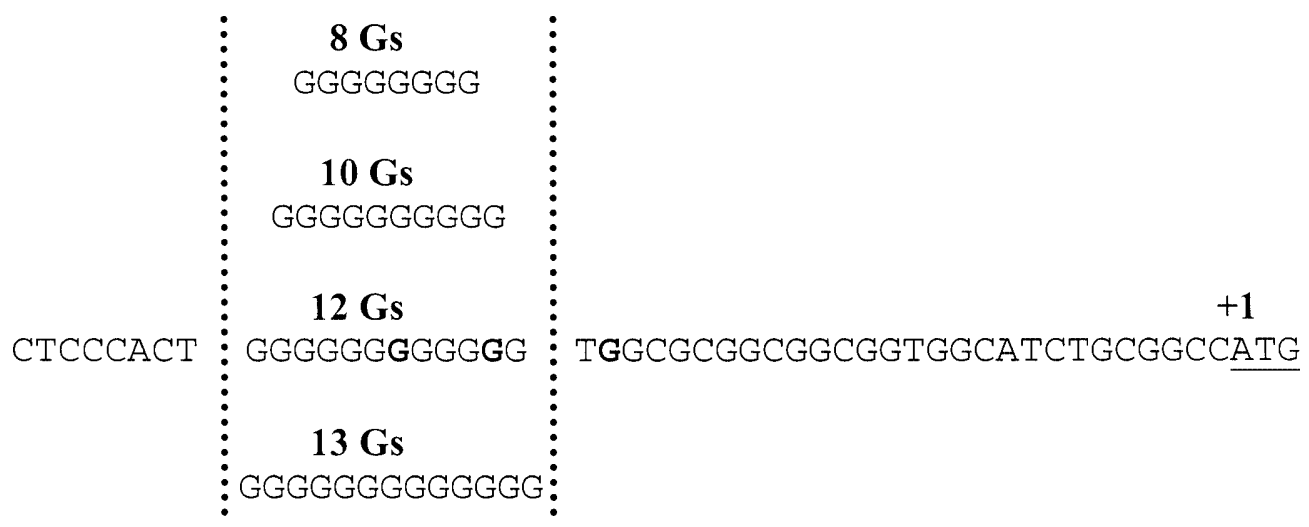

shows the T1551G variation (D517E), whereas both are heterozygous with respect to the common allele.

\section{PCR-SSCP analysis of the promoter region}

SSCP analysis of overlapping fragments located in the $A R N T$ promoter region, U1-U5 (compare Fig. 1), did not reveal any variant patterns. However, $5^{\prime}$-RACE experiments using RNA of three subjects of the cohort revealed a variation of the number of $G$ in a G-rich element harbouring three putative transcription start sites (Scheel and Schrenk 2000). As shown in Fig. 3, the number of Gs starting 29 bases upstream of the ATG translation start site varies between $8,10,12$, or 13 . Occurence of different alleles is either heterozygous ( $8 \mathrm{Gs} / 13 \mathrm{Gs}$ and $8 \mathrm{Gs} / 10 \mathrm{Gs}$, respectively) or homozygous (12 Gs / $12 \mathrm{Gs}$ ).

\section{Statistical analysis of CYP1A2 activity}

The $\mathrm{MR}_{\mathrm{C}}$ values were determined for all subjects of the cohort. Figure 4 shows the distribution of CYP1A2 activity for the different genotypes. Average CYP1A2 activities were higher in males than in females. Statistical analysis (analysis of variance, ANOVA), however, did not reveal significant differences in the distribution of CYP1A2 activities between genders or the polymorphic genotypes described in this study $(P<0.05)$. For the genetic variations with allelic frequencies below $1 \%$, statistical analysis could not be performed.

\section{Discussion}

A number of genetic variations could be detected in $A R N T$, a silent mutation in exon 7, two intronic mutations in exon 9 , and two single nucleotide exchanges in exon 16, both leading to an amino acid exchange. A significant correlation with altered CYP1A2 activity could not be found in caffeine testing for any of the genotypes. In addition, a variation in the number of Gs in a G-rich element upstream of the ATG translation start site could be identified that harbors several putative transcription start sites. It cannot be excluded that this variation has an influence on the transcriptional activity of the gene.

Being a useful screening method, SSCP analysis failed as a detection tool in this particular case. In a number of studies, the sensitivity of the method has been found to be within a range of $50 \%$ to $100 \%$ (for review, see Hayashi and Yandell 1993). In addition to various experimental parameters like electrophoresis temperature and gel composition, the detection power is affected by the DNA sequence, especially the neighboring base sequence of the changed base and can vary greatly from one fragment to another (Glavac and Dean 1993).

The two variations in exon 16, G1531A (D511N) and T1551G (D517E), seem to represent the only base exchanges in $A R N T$ found to date that lead to an altered amino acid sequence. Both are found in very low frequency. Exon 16 is not located within a known functional domain (see Fig. 1). Interestingly, the two additional codons in the murine Arnt gene are both located in exon 16 as well $(\mathrm{Li}$ et al. 1994). This region of $A R N T$ seems to be susceptible to genetic variations, including the evolutionary emergence of interspecies differences. This might be due to low functional importance, but effects of the variations on protein folding and function remain to be determined.

The G1531A polymorphism (D511N) has already been described by Cao and Hegele (2000). The T1551G variation (D517E) has not been described previously and thus represents a new genotype that is expected to lead to an amino acid exchange. From the structural point of view, both amino acid alterations observed are unlikely to cause dramatic changes in function. The silent variation in codon 189 has been reported not to affect CYP1A1 induction in lung cancer patients (Anttila et al. 2000). In this study, only healthy individuals were screened. As expected and described previously (Schrenk et al. 1998), average $M_{C}$ values were higher in male than in female Caucasians; there were no significant differences in this study, however. In the cohort investigated, significant differences in CYP1A2 activity between the genetic variations or polymorphisms of $A R N T$ could not be observed. In the case of genetic variants, the low frequencies did not allow statistical testing.

Putative polymorphic sites in other regions of $A R N T$ that influence regulation or function of the protein in a 

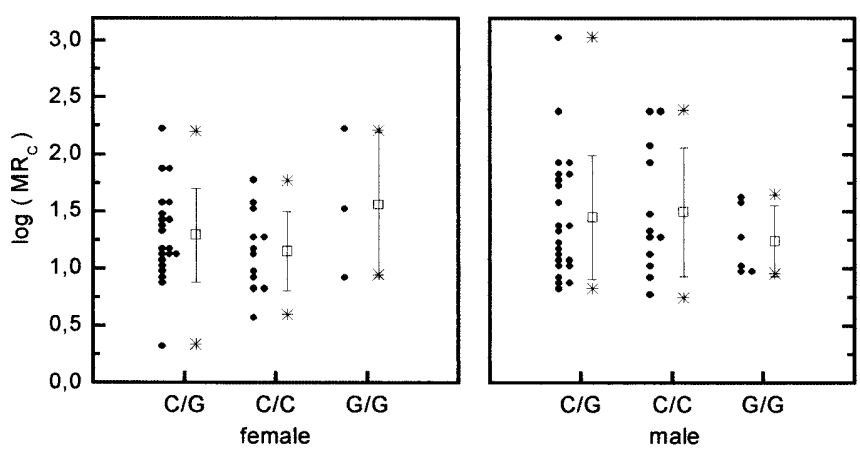

a
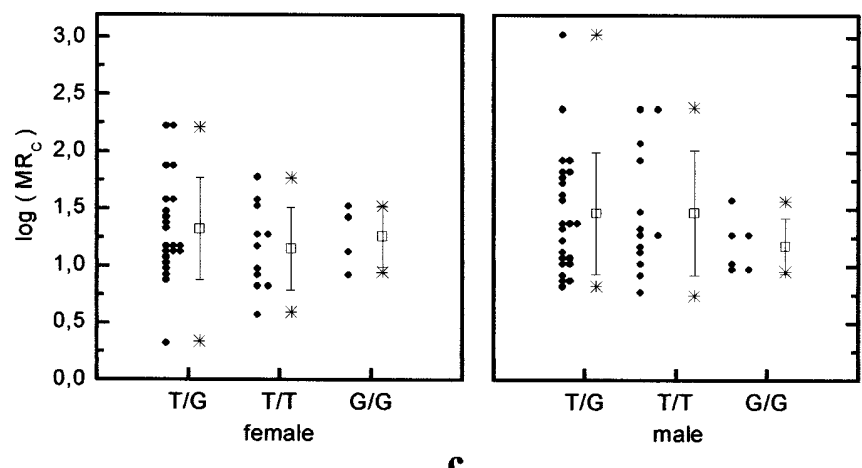

c
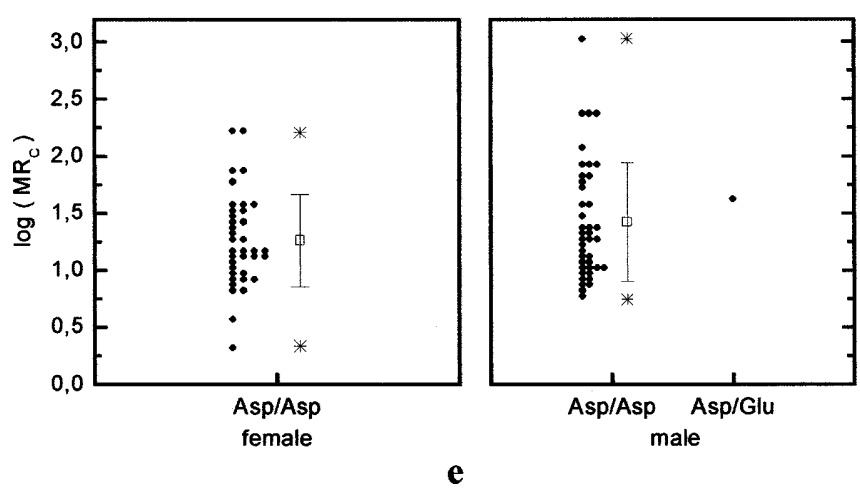

Fig. 4a-e. Distribution of CYP1A2-associated metabolic ratio $\left(M R_{C}\right)$ of urinary caffeine metabolites by genotypes of the $A R N T$ gene. CYP1A2 activities were assessed as urinary $M_{C}$ values, $[\mathrm{AFMU}+1 \mathrm{X}+1 \mathrm{U}] / 17 \mathrm{U}$, in a cohort of 79 healthy Caucasian volunteers. Maximum and minimum values are indicated by stars, medium

more dramatic way might be related to severe disorders or might even be lethal. Considering that ARNT contributes to a large number of essential pathways in the vertebrate cell, there are many possible influences on pathways and conditions. Cao and Hegele investigated subjects with partial lipodystrophy in their study (Cao and Hegele 2000). The allelic frequency of the Asn-coding allele was found to be 0.019 in Caucasians $(n=267)$ and 0.026 in Africans $(n=74)$. This is a higher frequency than observed in our healthy Caucasian population (allelic frequency $=0.01$ in female Caucasians, not observed in male Caucasians). Possibly, the higher frequency of the Asn-coding allele in patients with partial lipodystrophy is a trait correlated with the disease.
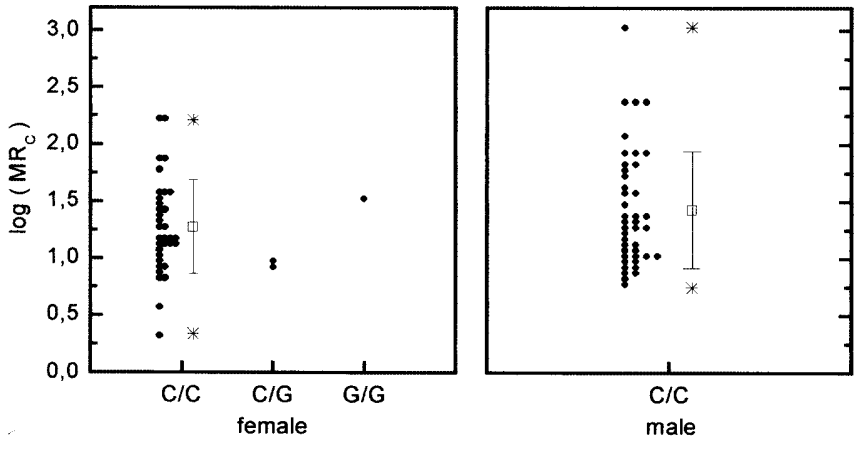

b
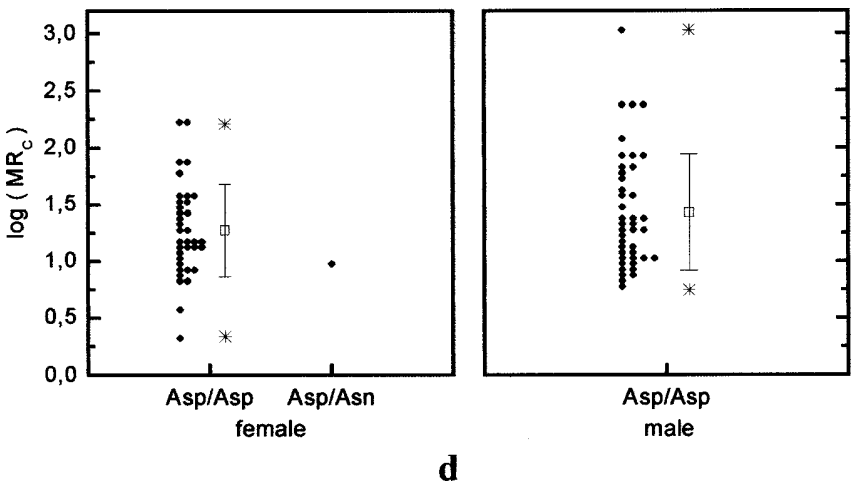

values by an open box. The error bars beside the distribution histograms indicate the 5th (lower) and 95th (upper) percentile values. a Codon 189, C537G. b Intron 9, position 326 from the $5^{\prime}$ splice donor site. c Intron 9, position 381 from the $5^{\prime}$ splice donor site. d Codon 511, G1531A. e Codon 517, T1551G

Because human $A R N T$ is involved in a variety of pathways that are related to homeostatic disorders, such as tumor growth (Semenza 1999; Sun et al. 2001), and because human $A R N T$ is involved in a chromosomal translocation in leukemia (Salomon-Nguyen et al. 2000), the genetic variations might affect other pathways and pathological conditions, respectively. In the light of this possibility, our data may provide a useful basis for further pathogenetic studies.

Acknowledgments The authors wish to thank Ruth Wartenberg for expert technical assistance and Dr. J. Fischer for taking blood samples. This work was supported by the Deutsche Forschungsgemeinschaft (Schr327/5-1). 


\section{References}

Anderson JL, Khan M, David WS, Mahdavi Z, Nuttall FQ, Krech E, West SG, Vance JM, Pericak-Vance MA, Nance MA (1999) Confirmation of linkage of hereditary partial lipodystrophy to chromosome 1q21-22. Am J Med Genet 82:161-165

Anttila S, Lei X-D, Elovaara E, Karjalainen A, Sun W, Vainio H, Hankinson O (2000) An uncommon phenotype of poor inducibility of CYP1A1 in human lung is not ascribable to polymorphisms in the AHR, ARNT, or CYP1A1 genes. Pharmacogenetics 10:741-751

Butler MA, Lang NP, Young JF, Caporaso NE, Vineis P, Hayes RB, Teitel CH, Massengill JP, Lawsen MF, Kadlubar FF (1992) Determination of CYP1A2 and NAT2 phenotypes in human populations by analysis of caffeine urinary metabolites. Pharmacogenetics 2:116127

Cao H, Hegele RA (2000) Human aryl hydrocarbon receptor nuclear translocator gene $(A R N T) \mathrm{D} / \mathrm{N} 511$ polymorphism. J Hum Genet 45:92-93

Chen H, Chrast R, Rossier C, Gos A, Antonarakis SE, Kudoh J, Yamaki A, Shindoh N, Maeda H, Minoshima S, Shimizu N (1995) Single-minded and Down syndrome? Nat Genet 10:9-10

Ema M, Suzuki M, Morita M, Hirose K, Sogawa K, Matsuda Y, Gotoh O, Saijoh Y, Fujii H, Hamada H, Fujii-Kuriyama Y (1996) cDNA cloning of a murine homologue of Drosophila single-minded, its mRNA expression in mouse development, and chromosome localization. Biochem Biophys Res Commun 218:588-594

Glavac D, Dean M (1993) Optimization of the single-strand conformation polymorphism (SSCP) technique for detection of point mutations. Hum Mutat 2:404-414

Hayashi K, Yandell DW (1993) How sensitive is PCR-SSCP? Hum Mutat 2:338-346

Jaeckel S, Epplen JZ, Kauth M, Miterski B, Tschentscher F, Epplen C (1998) Polymerase chain reaction - single strand conformation polymorphism or how to detect reliably and efficiently each sequence variation in many samples and many genes. Electrophoresis 19:3055-3061

Johnson BS, Brooks BA, Reyes H, Hoffman EC, Hankinson O (1992) An MspI RFLP in the human ARNT gene, encoding a subunit of the nuclear form of the Ah (dioxin) receptor. Hum Mol Genet 1:351

Johnson B, Brooks BA, Heinzmann C, Diep A, Mohandas T, Sparkes RS, Reyes H, Hoffman E, Lange E, Gatti RA, Xia YR, Lusis AJ, Hankinson O (1993) The Ah receptor nuclear translocator gene $(A R N T)$ is located on q21 of human chromosome 1 and on mouse chromosome 3 near Cf-3. Genomics 17:592-598

Kozak KR, Abbott B, Hankinson O (1997) ARNT-deficient mice and placental differentiation. Dev Biol 191:297-305

Li H, Dong L, Whitlock JP Jr (1994) Transcriptional activation function of the mouse Ah receptor nuclear translocator. J Biol Chem 269:28098-28105

Maltepe E, Schmidt JV, Baunoch D, Bradfield CA, Simon MC (1997) Abnormal angiogenesis and responses to glucose and oxygen deprivation in mice lacking the protein ARNT. Nature 386:403-407
Okey AB, Bondy GP, Mason ME, Nebert DW, Forster-Gibson CJ, Muncan J, Dufresne MJ (1980) Temperature-dependent cytosolto-nucleus translocation of the $\mathrm{Ah}$ receptor for 2,3,7,8tetrachlorodibenzo- $p$-dioxin in continuous cell culture lines. J Biol Chem 255:11415-11422

Pajukanta P, Nuotio I, Terwilliger JD, Porkka KVK, Ylitalo K, Pihlajamaki J, Suomalainen AJ, Syvanen AC, Lehtimaki T, Viikari JS, Laakso M, Taskinen MR, Ehnholm C, Peltonen L (1998) Linkage of familial combined hyperlipidaemia to chromosome 1q21-q23. Nat Genet 18:369-373

Reyes H, Reisz-Porszasz S, Hankinson O (1992) Identification of the Ah receptor nuclear translocator protein (Arnt) as a component of the DNA binding form of the Ah receptor. Science 256:11931195

Rowlands JC, Gustafsson JA (1997) Aryl hydrocarbon receptormediated signal transduction. Crit Rev Toxicol 27:109-134

Salomon-Nguyen F, Della-Valle V, Mauchauffée M, Busson-LeConiat M, Ghysdael J, Bernard OA (2000) The $\mathrm{t}(1 ; 12)(\mathrm{q} 21 ; \mathrm{p} 13)$ translocation of human acute myeloblastic leukemia results in a TEL-ARNT fusion. Proc Natl Acad Sci USA 97:6757-6762

Scheel J, Schrenk D (2000) Genomic structure of the human aryl hydrocarbon nuclear translocator gene $(h A R N T)$. Hum Genet 107:397-399

Schmidt JV, Bradfield CA (1996) Ah receptor signaling pathways. Annu Rev Cell Dev Biol 12:55-89

Schrenk D (1998) Impact of dioxin-type induction of drug-metabolizing enzymes on the metabolism of endo- and xenobiotics. Biochem Pharmacol 55:1155-1162

Schrenk D, Brockmeier D, Morike K, Bock KW, Eichelbaum M (1998) A distribution study of CYP1A2 phenotypes among smokers and non-smokers in a cohort of healthy Caucasian volunteers. Eur J Clin Pharmacol 53:361-367

Semenza GL (1999) Regulation of mammalian $\mathrm{O}_{2}$ homeostasis by hypoxia-inducible factor 1. Annu Rev Cell Dev Biol 15:551-578

Smart J, Daly AK (2000) Variation in induced CYP1A1 levels: relationship to CYP1A1, Ah receptor and GSTM1 polymorphisms. Pharmacogenetics 10:11-24

Sogawa K, Nakano R, Kobayashi A, Kikuchi Y, Ohe N, Matsushita N, Fujii-Kuriyama Y (1995) Possible function of Ah receptor nuclear translocator (Arnt) homodimer in transcriptional regulation. Proc Natl Acad Sci USA 92:1936-1940

Sun X, Kanwar JR, Leung E, Lehnert K, Wang D, Krissansen GW (2001) Gene transfer of antisense hypoxia inducible factor-1 alpha enhances the therapeutic efficacy of cancer immunotherapy. Gene Ther 8:638-645

Watanabe T, Imoto I, Kosugi Y, Fukuda Y, Mimura J, Fujii Y, Isaka K, Takayama M, Sato A, Inazawa J (2001) Human arylhydrocarbon receptor repressor $(A H R R)$ gene: genomic structure and analysis of polymorphism in endometriosis. J Hum Genet 46:342-346

Wenger RH, Gassmann M (1997) Oxygen(es) and the hypoxiainducible factor-1. Biol Chem 378:609-616

Wilson CL, Safe S (1998) Mechanism of ligand-induced aryl hydrocarbon receptor-mediated biochemical and toxic responses. Toxicol Pathol 26:657-671 